\title{
MECHANICAL PROPERTIES, MORPHOLOGY, AND HYDROLYTIC DEGRADATION BEHAVIOR OF POLYLACTIC ACID / THERMOPLASTIC POLYURETHANE BLENDS
}

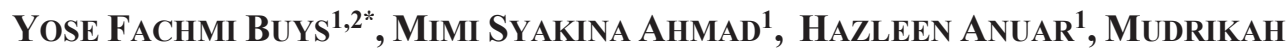 \\ Sofia MAHMUd ${ }^{1}$, NUR AIMI MOHD NASIR ${ }^{1}$ \\ ${ }^{1}$ Department of Manufacturing and Materials Engineering, International Islamic University \\ Malaysia, Kuala Lumpur, Malaysia \\ ${ }^{2}$ Department of Mechanical Engineering, University of Malaya, Kuala Lumpur, Malaysia \\ *Corresponding author: yose@um.edu.my \\ (Received: 30 $0^{\text {th }}$ December 2018; Accepted: 28 th August 2019; Published on-line: $20^{\text {th }}$ January 2020)
}

ABSTRACT: Polylactic acid (PLA) has attracted tremendous interest to be utilized as the replacement for petroleum-based polymers as it possesses good biodegradability, can be derived from renewable sources, and shows high mechanical strength. However, its inherent brittleness and low toughness has limited its usage in broader applications. In this work, PLA was melt blended with tough thermoplastic polyurethanes (TPU) in order to produce eco-friendly polymeric materials with balanced mechanical properties. Moreover, the miscibility and the hydrolytic degradation behaviour of PLA/TPU blends were also investigated as it is important to control material degradation behaviour in some applications. Five compositions of specimens, i.e. neat PLA, PLA/TPU 75/25 vol\%, PLA/TPU 50/50 vol\%, PLA/TPU 25/75 vol\%, and neat TPU, were prepared by melt blending PLA with TPU using an internal mixer, followed by compression moulding. Tensile and impact tests were performed to evaluate the mechanical properties. From the tests, it was apparent that the elongation-at-break and impact strength of the blends increased as the TPU content increased. Dynamic Mechanical Analysis (DMA) and Scanning Electron Microscopy (SEM) observation were conducted to evaluate the miscibility of PLA/TPU blends. DMA results of the blends revealed two tangent delta peaks, indicating that the blends were immiscible, and the SEM micrographs supported this trend. Finally, hydrolytic degradation behaviour of PLA, TPU and PLA/TPU blends was investigated by measuring the weight loss after immersion of the specimens in alkaline solution at a predetermined time, i.e. every 24 hours for up to 8 days. It was found that the degradation behaviour is affected by blend composition, where PLA/TPU 50/50 vol\% showed the fastest degradation rate. This result might be ascribed to the co-continuous morphology shown in the PLA/TPU blend 50/50 vol\%.

ABSTRAK: Polilaktik asid (PLA) telah menarik banyak minat untuk digunakan sebagai pengganti polimer berasaskan petroleum, kerana ia mempunyai biodegradabiliti yang baik, boleh diperolehi daripada sumber yang boleh diperbaharui, dan mempunyai kekuatan mekanikal yang tinggi. Walau bagaimanapun, kerapuhan dan keliatannya yang rendah telah menghadkan penggunaannya dalam aplikasi yang lebih luas. Dalam kajian ini, leburan PLA dicampurkan dengan poliuretan thermoplastik (TPU) bagi menghasilkan bahan polimer yang mesra alam beserta dengan sifat-sifat mekanikal yang seimbang. Selain itu, daya kebolehcampuran dan degradasi hidrolitik daripada campuran PLA/ TPU juga telah dikaji kerana bagi sesetengah aplikasi, faktor degradasi adalah sangat penting. Bagi menghasilkan lima komposisi sampel, iaitu PLA tulen, PLA/TPU 75/25 vol\%, PLA/TPU 50/50 vol\%, 
PLA/TPU 25/75 vol\%, dan TPU tulen, PLA dan TPU telah dicairkan dan diadun menggunakan mesin pencampur internal, diikuti dengan kaedah pengacuan kompresi. Untuk mengkaji sifat-sifat mekanikal, ujian regangan dan impak telah dijalankan. Hasil ujian tersebut menunjukkan peningkatan nilai pemanjangan pada titik putus dan kekuatan impak, seiring dengan peningkatan komposisi TPU. Manakala, penilaian daya kebolehcampuran diantara PLA dan TPU dijalankan menggunakan analisis mekanikal dinamik (DMA) dan mikroskop pengimbas elektron (SEM). Keputusan DMA, hasil daripada campuran tersebut mendedahkan dua puncak tangen delta, menunjukkan bahawa dua campuran tersebut tidak memiliki daya bolehcampur yang baik. Kesimpulan ini disokong pula oleh gambar mikro dari hasil ujian SEM. Akhir sekali, degradasi hidrolitik PLA, TPU dan campuran PLA/TPU dikaji melalui pengukuran berat sampel setelah direndam di dalam larutan alkali pada masa yang ditetapkan, iaitu setiap 24 jam sehingga 8 hari. Hasil daripada ujian tersebut mendapati degradasi hidrolitik dipengaruhi oleh komposisi campuran. Campuran PLA/TPU dengan komposisi 50/50 vol\% menunjukkan kadar penurunan berat yang paling cepat. Hasil ujian ini mungkin boleh dikaitkan dengan sifat morfologi co-continuous yang ditunjukkan dalam campuran PLA/TPU 50/50 vol\%.

KEY WORDS: Polylactic Acid, Thermoplastic Polyurethane, Polymer Blends, Mechanical Properties, and Hydrolytic Degradation.

\section{INTRODUCTION}

The interest in using degradable polymeric materials derived from renewable resources has been increasing day by day due to intensified environmental awareness from society and concerns about the depletion of petrochemical based plastics. Among other alternatives, polylactic acid (PLA), seems to be a polymer of choice due to its numerous advantages, such as biodegradability, compostability, recyclability, ability to be produced from renewable resources, as well as possessing good mechanical strength and stiffness. However, PLA's inherent brittleness, indicated by low values of elongation at break and impact strength, has limited its usage in broader applications [1-2], such as the applications that need plastic deformation at higher stress levels (e.g., screws and fracture fixation plates) [3]. One of the techniques to overcome the brittleness of PLA is by blending with other elastomeric polymers, such as thermoplastic polyurethane (TPU). Several recent reports have highlighted the mechanical properties of PLA/TPU blends, where it has been reported that TPU addition into PLA increased the elongation at break of the blends, hence improving the brittle nature of PLA [4-9].

On the other hand, in real applications, in addition to mechanical properties it is also important to investigate the degradation behaviour of materials. Polymer-based products are required to degrade in a controlled manner [10]. There are instances where materials in the products need to degrade in relatively short time after being used [11], such as food and toiletries packaging materials in composting environments [10]. There are also cases where materials must have low and controllable degradation rates, especially in biomaterials applications, such as in bone implants or drug release applications [11]. From the previous reports highlighting properties of PLA/TPU blends [4-9, 12-13], only a few focused on degradation behaviour of the blends [12-13], and to the best of our knowledge, there have been no reports to date discussing hydrolytic degradation behaviour of the blends. Therefore, in this work, PLA/TPU blends were produced, and the mechanical properties, miscibility, as well as hydrolytic degradation behaviour of the blends were investigated. 


\section{EXPERIMENTAL}

\subsection{Materials}

PLA used in this work was 3051D from NatureWorks LLC, with density of $1.25 \mathrm{~g} / \mathrm{cm}^{3}$ and melt flow index of 10-25 g/10 min. While the TPU used was Desmopan 8785A from Bayer Material Science with density of $1.20 \mathrm{~g} / \mathrm{cm}^{3}$.

\subsection{Sample Preparation}

Prior to mixing, PLA and TPU were dried in an oven at $60^{\circ} \mathrm{C}$ for at least $10 \mathrm{~h}$, in order to remove moisture. PLA was melt blended with TPU using a Hake internal mixer with a 50 $\mathrm{cm}^{3}$ cell at $200^{\circ} \mathrm{C}$, mixing speed of $50 \mathrm{rpm}$ for $15 \mathrm{~min}$. The blend ratios of PLA/TPU were $75 / 25,50 / 50$, and $25 / 75 \mathrm{vol} \%$. For further characterization, the blends were then compression moulded using an $\mathrm{XH}-406 \mathrm{~B}$ Tablet Press machine at $200^{\circ} \mathrm{C}$ with 5 min preheating time and 5 min pressing time under $15 \mathrm{MPa}$ pressure. Neat PLA and TPU specimens were also produced by directly pressing the respective pellets.

\subsection{Mechanical Properties Characterization}

A tensile strength test was conducted to determine the Young's modulus, tensile strength, and elongation at break of the specimens. It was performed according to ASTM D638 standard, using a universal testing machine model AGS-X (Shimadzu Corp.) with 5 $\mathrm{mm} / \mathrm{min}$ strain rate. Meanwhile, the impact strength of the specimens was evaluated using a notched Charpy method, according to ASTM D256 standard. The test was carried out by Dynisco Polymer Test Advance Pendulum Impact, using a $7.5 \mathrm{~J}$ hammer.

\subsection{Miscibility and Morphology Evaluation}

Dynamic Mechanical Analysis (DMA) measurement was performed to study the miscibility of the PLA/TPU blend. The measurement was carried out using a Pyris Diamond DMA (Perkin Elmer) with single cantilever using 3-points bending mode over the temperature range of -100 to $160^{\circ} \mathrm{C}$ at a heating rate of $5^{\circ} \mathrm{C} / \mathrm{min}$ and a frequency of $1 \mathrm{~Hz}$. Meanwhile, in order to investigate the phase morphology of PLA/TPU blend, Scanning Electron Microscopy (SEM) observation was performed at room temperature using an InTouch Scope JSM-IT100 (Jeol) on the fractured surface of the specimen. Before being inserted into the observation chamber, the sample was coated with palladium in order to make the surface conductive.

\subsection{Hydrolytic Degradation Test}

Alkaline hydrolytic degradation test was performed by immersing the specimens with 10 $\mathrm{mm} \times 10 \mathrm{~mm} \times 1 \mathrm{~mm}$ dimension in $10 \mathrm{ml}$ of $1 \mathrm{M} \mathrm{NaOH}$ aqueous solution of $\mathrm{pH} 12$ at $30^{\circ} \mathrm{C}$ for a predetermined period of time. To obtain the initial weight of samples before degradation, all the specimens were dried in an oven with $50^{\circ} \mathrm{C}$ for 6 hours. After hydrolyses, specimens were washed in distilled water at room temperature, followed by a few hours drying at room temperature, before being dried in the oven at $50^{\circ} \mathrm{C}$ for 2 days. The final weight after drying was measured to determine the weight loss. Similar procedures were conducted by other researchers in previous papers [14-16]. During the degradation test, a digital camera was also used to record the physical change of specimens after a predetermined period of degradation time. 


\section{RESULTS AND DISCUSSION}

\subsection{Mechanical Properties}

Fig. 1 shows the stress vs. strain graph of the PLA, TPU and PLA/TPU blends, and the values of Young's modulus, tensile strength, and elongation at break is tabulated in Table 1. From Fig. 1 and Table 1, it is apparent that neat PLA is a brittle material with only less than $3 \%$ elongation at break, similar with the works had been reported by others $[3,6]$. It is also obvious that addition of TPU to PLA brought the blends into more flexible materials, indicated by the increase of elongation at break. Significant increase in elongation at break was observed in PLA/TPU 25/75 specimen that elongated more than $240 \%$ before break. However, addition of TPU also brought on a decrease of Young's modulus and tensile strength. Similar trends of increase in elongation at break and decrease in Young's modulus and tensile strength of PLA/TPU blends as the amount of TPU increased had also been reported in other works [4-9]. Therefore, by adjusting the blend composition, one may obtain PLA/TPU based materials with desirable mechanical properties.

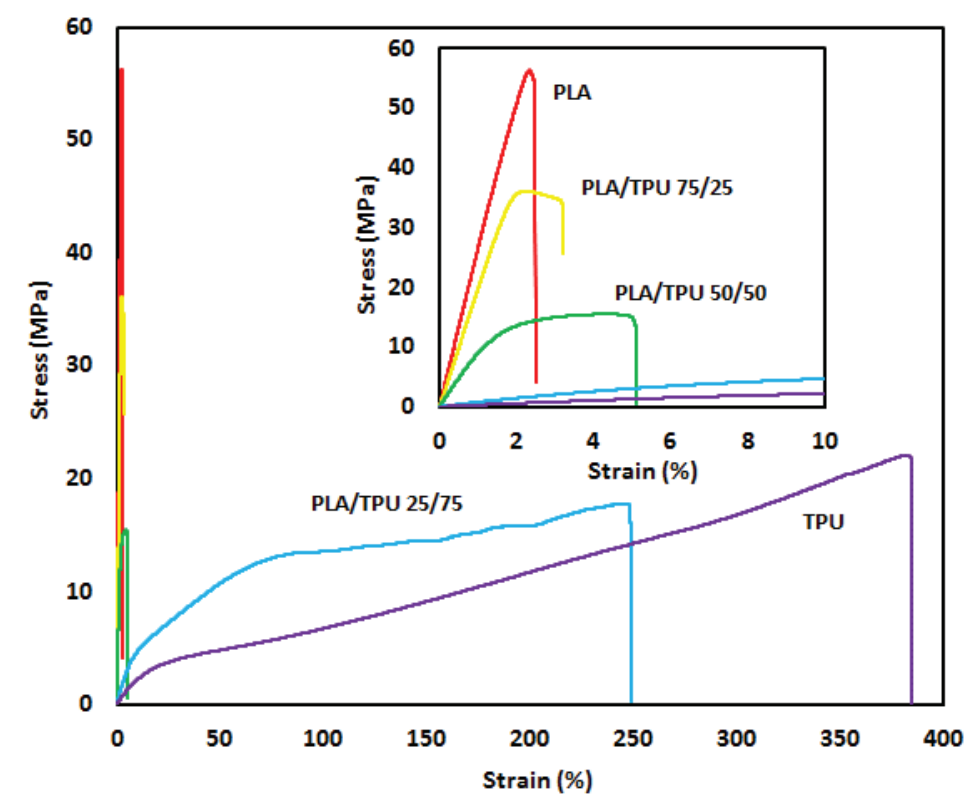

Fig. 1. Stress vs strain curves of PLA, TPU and PLA/TPU blends

Table 1: Young's modulus, tensile strength and elongation at break values of PLA, TPU and PLA/TPU blend

\begin{tabular}{|c|c|c|c|}
\hline Samples & $\begin{array}{c}\text { Young's Modulus } \\
\text { (MPa) }\end{array}$ & $\begin{array}{c}\text { Tensile Strength } \\
\text { (MPa) }\end{array}$ & $\begin{array}{c}\text { Elongation at } \\
\text { break (\%) }\end{array}$ \\
\hline PLA & 2749.52 & 56.30 & 2.49 \\
\hline PLA/TPU 75/25 & 1871.64 & 36.13 & 3.21 \\
\hline PLA/TPU 50/50 & 989.07 & 22.47 & 5.11 \\
\hline PLA/TPU 25/75 & 69.93 & 17.74 & 248.62 \\
\hline TPU & 24.873 & 22.03 & 384.63 \\
\hline
\end{tabular}


Impact strength of PLA, TPU and PLA/TPU blends is shown in Fig. 2. From this figure, it is clear that the addition of TPU increased the toughness of PLA. The elastomeric nature of TPU improved the crack propagation resistance of PLA/TPU blends. It is also interesting to note that drastic increase in impact strength was observed starting from the addition of $50 \%$ TPU. It is believed that this drastic change of impact strength correlates with the morphology development of the blends, which is described in the next section.

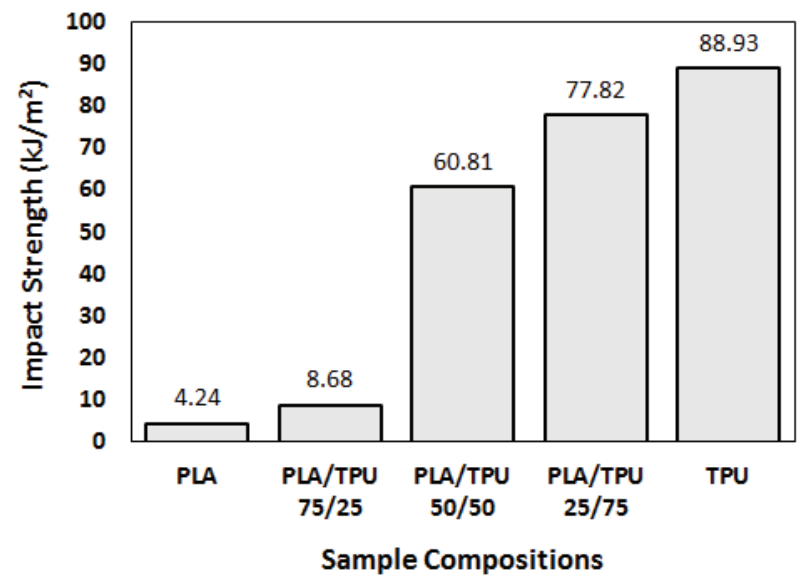

Fig. 2. Impact strength of PLA, TPU and PLA/TPU blends

\subsection{Miscibility and Morphology}

DMA is an excellent tool to characterize the miscibility of polymer blends, due to its sensitivity to detect the glass transition temperature (Tg) of the specimens. Fig. 3 shows the tangent delta curves of PLA, TPU and PLA/TPU blends obtained from DMA measurement. The peak of tangent delta in DMA represents the Tg of the specimens. It is apparent that the neat PLA and the neat TPU used in this work showed the $\mathrm{Tg}$ around $62^{\circ} \mathrm{C}$ and $-25^{\circ} \mathrm{C}$, respectively. While it is interesting to note that all PLA/TPU blends showed two tangent delta peaks, i.e. the peaks in the region of $-40^{\circ} \mathrm{C}$ until $-25^{\circ} \mathrm{C}$, which correlated to the glass transition temperature $\left(T_{\mathrm{g}}\right)$ of TPU part in the blends, and those in the region of $60^{\circ} \mathrm{C}$ until $65^{\circ} \mathrm{C}$, which correlated to the $T_{\mathrm{g}}$ of PLA part in the blends. The existence of two $T_{\mathrm{g}} \mathrm{s}$ indicates the immiscibility of PLA and TPU in PLA/TPU blends.

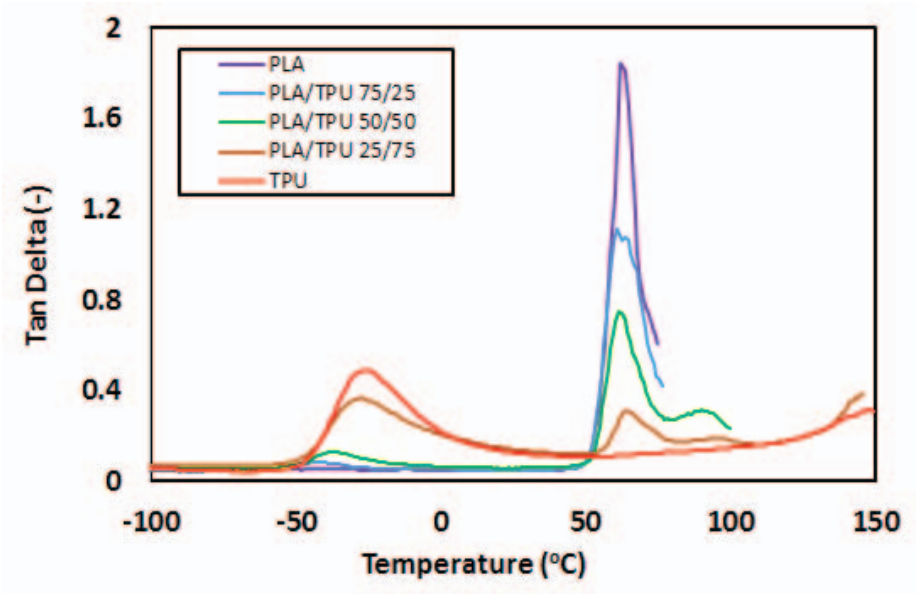

Fig. 3. Tangent delta of PLA, TPU, and PLA/TPU blends 
SEM micrographs of neat PLA, PLA/TPU blends, and neat TPU are shown in Fig. 4. While a single phase is observed in the micrographs of pristine PLA as well as in that of pristine TPU, two different phases are observed in the micrographs of PLA/TPU blends, supporting the immiscibility trend of the blends, as indicated by the DMA result. The micrographs of PLA/TPU 75/25 and PLA/TPU 25/75 show many "droplet like" phases, suggesting these two compositions exhibited "sea-island" morphology. Considering the amount of the droplets were less than the main phase, it is reasonable to deduce that the droplets, or the "island" phase in PLA/TPU 75/25 was the TPU, and droplets or the island phase in PLA/TPU 25/75 was the PLA. Meanwhile, co-continuous morphology was observed in the PLA/TPU 50/50 specimen. Correlating these morphology observations with the impact strength results exhibited in Fig. 2, it is sensible to conclude that the continuity of TPU phase in the blend plays a significant role in increasing the impact strength of PLA/TPU blends.

It is known that morphology of polymer blends affects the mechanical and properties of the materials $[4,8]$. Here, it is believed that the drastic increase of impact strength of PLA/TPU 50/50 specimen has positive correlation with continuity of the TPU phase in the sample.
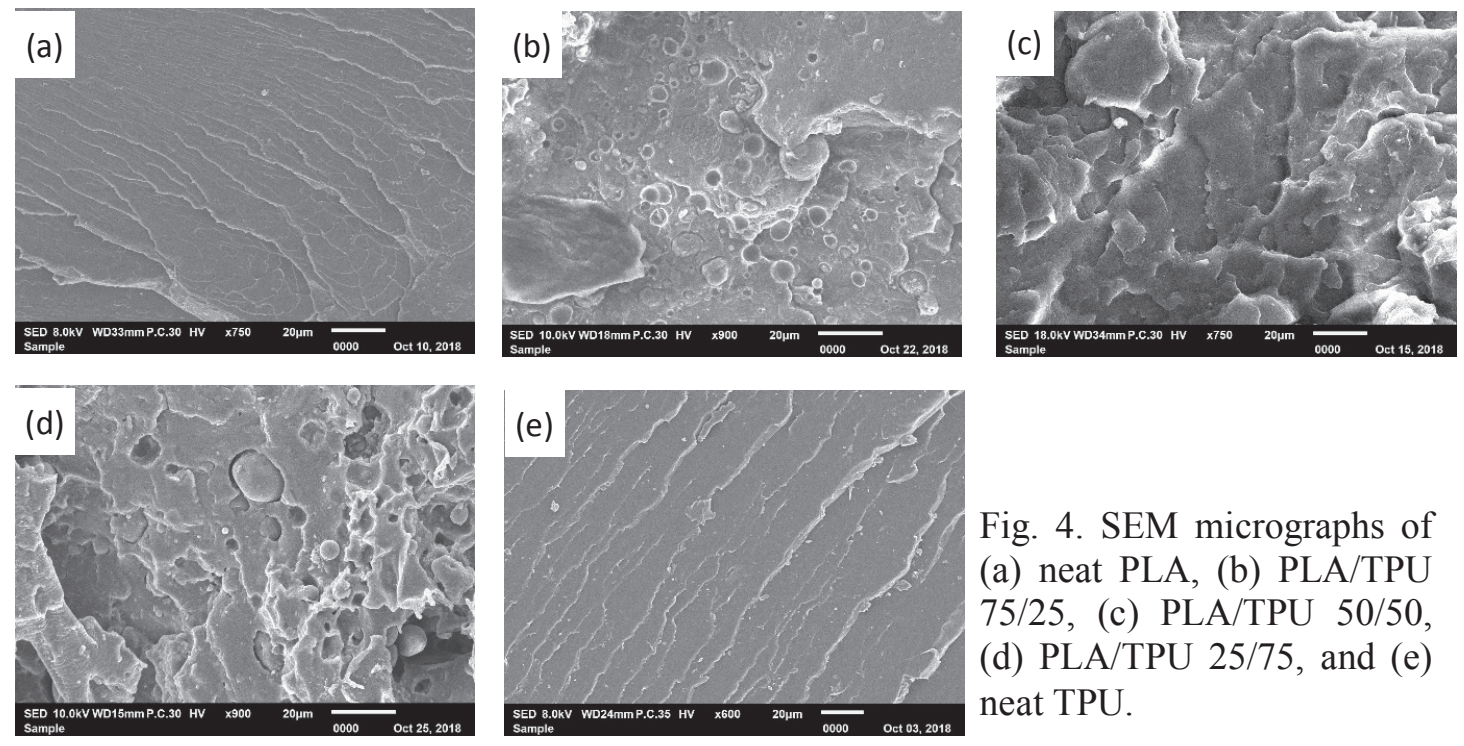

Fig. 4. SEM micrographs of (a) neat PLA, (b) PLA/TPU 75/25, (c) PLA/TPU 50/50, (d) PLA/TPU 25/75, and (e) neat TPU.

\subsection{Hydrolytic Degradation Behavior}

Fig. 5 shows the weight changes of PLA, TPU, and PLA/TPU blends after a predetermined time of immersion in alkaline solution while the physical changes of the specimens is shown in Fig. 6. From Fig. 5, it can be seen that TPU shows the slowest hydrolytic degradation rate with around $80 \%$ of the weight still remaining after 8 days (192 hours) of immersion. Meanwhile, neat PLA completely degraded after 8 days, confirming its good degradability. However, it is interesting to note that the relationship between blend composition and hydrolytic degradation behaviour is not linear. PLA/TPU 50/50 became the fastest blend to degrade, followed by PLA/TPU 75/25. While the degradation curve of PLA/TPU 25/75 lied between those of neat PLA and neat TPU. 


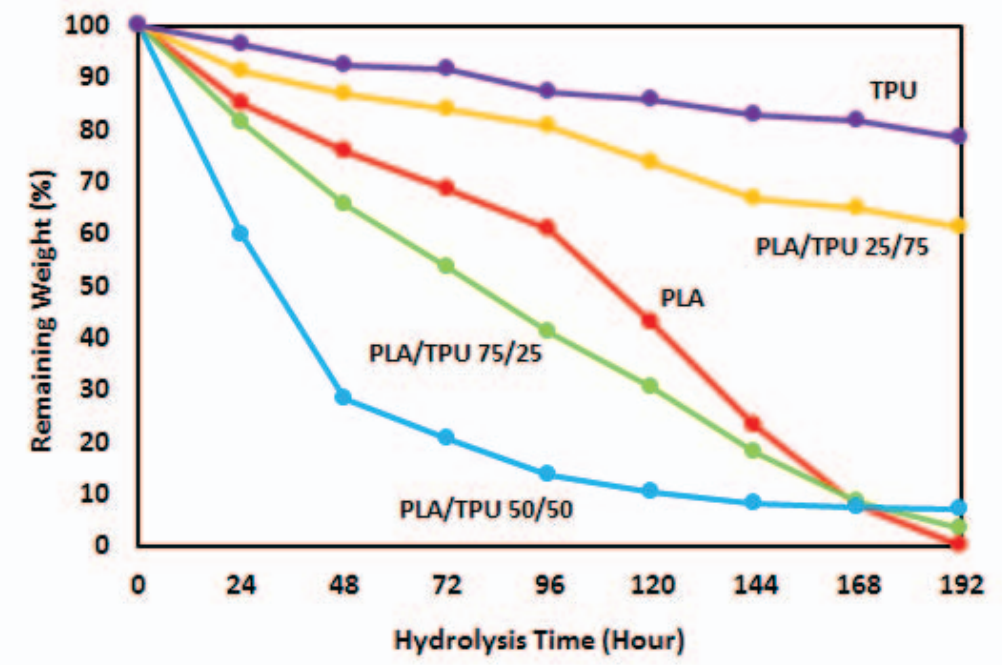

Fig. 5 Weight remaining of PLA, TPU and PLA/TPU blends after hydrolysis test
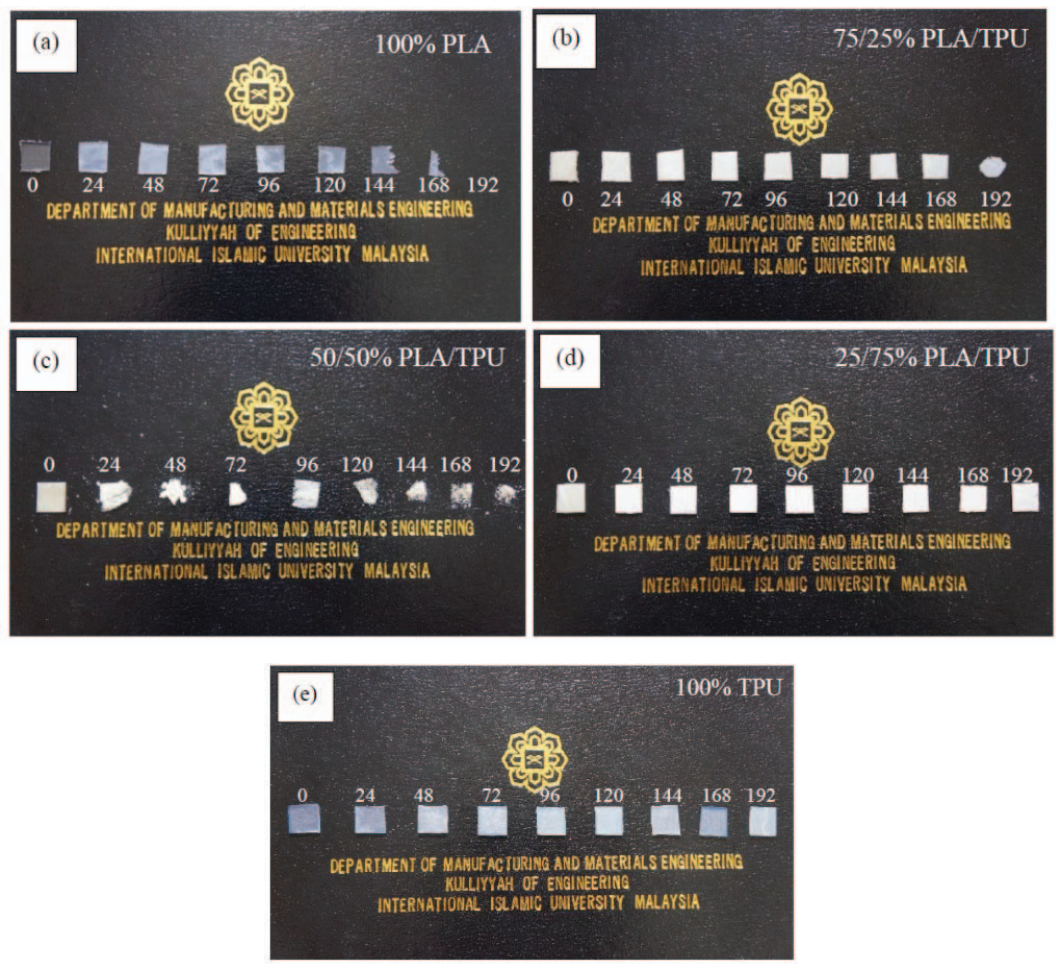

Fig. 6. Physical change of specimens after predetermined time of immersion in alkaline solution for (a) neat PLA, (b) PLA/TPU 75/25, (c) PLA/TPU 50/50, (d) PLA/TPU 25/75, and (e) neat TPU.

Several papers also reported that degradation behaviour of PLA blends is affected by blend composition [17] and that the relationship is sometimes not linear [15]. In this work, it is believed that the hydrolytic degradation behaviour is related to the sequence of alkaline 
solution attacking the ester bond in the specimens, as well as the composition and morphology of the blends. It is thought that the degradation in the alkaline solution started from the surface, and PLA degraded faster compared with TPU. The PLA/TPU 75/25 degraded faster than the neat PLA might be due to the relative amount of PLA in the blend being less than in the neat one. PLA in PLA/TPU 75/25 blend acts as the sea phase where TPU acts as the island phase. Therefore, when the ester bond in the PLA phase was attacked by the alkaline solution, the dimension stability of the specimen collapsed, causing faster weight loss. Similar reasoning was applied to PLA/TPU 50/50 which has a lower PLA portion, so that the specimen dimension stability collapsed faster compared to PLA/TPU $75 / 25$ and the neat PLA. This situation was confirmed with the fastest collapsing shape of PLA/TPU 50/50 blend as depicted in Fig. 6.

Meanwhile, PLA/TPU 25/75 degraded slower than neat PLA. This is because in this blend, the PLA no longer became a continuous phase, and the morphology of the blend was thought to be sea-island structure, with TPU becoming the sea phase and PLA becoming the island phase. Therefore, the surface of the specimens was thought to be dominated by TPU, causing slower degradation rate compared to the neat PLA. Here, Fig. 6 also confirmed the dimension stability of the PLA/TPU 25/75 and the neat TPU after up to 8 days of exposure in alkaline solution.

\section{CONCLUSION}

PLA/TPU blends were successfully fabricated by melt blending process. From the mechanical properties evaluation, it is clear that the brittleness and the low toughness of PLA was improved as the TPU content increased. DMA measurement of PLA/TPU blends showed the appearance of two $T_{\mathrm{g}}$ 's, indicating that the blends were immiscible. The immiscibility of the PLA/TPU blend has also been supported by SEM micrographs. It has also been confirmed that blend composition affects the morphology of the blends. Finally the hydrolytic degradation behaviour of PLA, TPU and PLA/TPU blends showed some interesting behaviour, where PLA/TPU 50/50 showed the fastest degradation rate, followed by PLA/TPU 75/25, and the neat PLA. This degradation behaviour is believed to be strongly related with the morphology of the specimens.

\section{ACKNOWLEDGEMENT}

This work was supported by Research Initiative Grant Scheme RIGS16-085-0249 and RPDF18-010-0010, both from International Islamic University Malaysia.

\section{REFERENCES}

[1] Imre B, Bedő D, Domján A, Schön P, Vancso GJ, Pukánszky B. (2013) Structure, properties and interfacial interactions in poly (lactic acid)/polyurethane blends prepared by reactive processing. European Polymer Journal, 49(10):3104-3113.

[2] Wang M, Wu Y, Li YD, Zeng JB. (2017) Progress in toughening poly (lactic acid) with renewable polymers. Polymer Reviews, 57(4):557-93.

[3] Rasal RM, Janorkar AV, Hirt DE. (2010) Poly (lactic acid) modifications. Progress in Polymer Science, 35(3):338-56.

[4] Feng F, Ye L. (2011) Morphologies and mechanical properties of polylactide/thermoplastic polyurethane elastomer blends. Journal of Applied Polymer Science, 119(5):2778-2783.

[5] Han JJ, Huang HX. (2011) Preparation and characterization of biodegradable polylactide/thermoplastic polyurethane elastomer blends. Journal of Applied Polymer Science, 120(6):3217-23. 
[6] Mi HY, Salick MR, Jing X, Jacques BR, Crone WC, Peng XF, Turng LS. (2013) Characterization of thermoplastic polyurethane/polylactic acid (TPU/PLA) tissue engineering scaffolds fabricated by microcellular injection molding. Materials Science and Engineering C, 33(8):4767-4776.

[7] Jašo V, Cvetinov M, Rakić S, Petrović ZS. (2014) Bio-plastics and elastomers from polylactic acid/thermoplastic polyurethane blends. Journal of Applied Polymer Science, 131(22):41104.

[8] Jing X, Mi HY, Peng XF, Turng LS. (2015) The morphology, properties, and shape memory behavior of polylactic acid/thermoplastic polyurethane blends. Polymer Engineering and Science, 55(1):70-80.

[9] Oliaei E, Kaffashi B, Davoodi S. (2016) Investigation of structure and mechanical properties of toughened poly (1-lactide)/thermoplastic poly (ester urethane) blends. Journal of Applied Polymer Science, 133(15):43104.

[10] Siracusa V, Rocculi P, Romani S, Dalla Rosa M. (2008) Biodegradable polymers for food packaging: a review. Trends in Food Science and Technology, 19(12):634-43.

[11] Elsawy MA, Kim KH, Park JW, Deep A. (2017) Hydrolytic degradation of polylactic acid (PLA) and its composites. Renewable and Sustainable Energy Reviews, 79:1346-52.

[12] Jašo V, Glenn G, Klamczynski A, Petrović ZS. (2015) Biodegradability study of polylactic acid/thermoplastic polyurethane blends. Polymer Testing, 47:1-3.

[13] Dogan SK, Boyacioglu S, Kodal M, Gokce O, Ozkoc G. (2017) Thermally induced shape memory behavior, enzymatic degradation and biocompatibility of PLA/TPU blends:"Effects of compatibilization". Journal of the Mechanical Behavior of Biomedical Materials, 71:349-61.

[14] Li MX, Kim SH, Choi SW, Goda K, Lee WI. (2016) Effect of reinforcing particles on hydrolytic degradation behavior of poly (lactic acid) composites. Composites Part B: Engineering, 96:248-54.

[15] Shirahase T, Komatsu Y, Tominaga Y, Asai S, Sumita M. (2006) Miscibility and hydrolytic degradation in alkaline solution of poly (L-lactide) and poly (methyl methacrylate) blends. Polymer, 47(13):4839-4844.

[16] Gu X, Raghavan D, Nguyen T, VanLandingham MR, Yebassa D. (2001) Characterization of polyester degradation using tapping mode atomic force microscopy: exposure to alkaline solution at room temperature. Polymer Degradation and Stability,74(1):139-49.

[17] Yang S, Madbouly SA, Schrader JA, Srinivasan G, Grewell D, McCabe KG, Kessler MR, Graves WR. (2015) Characterization and biodegradation behavior of bio-based poly (lactic acid) and soy protein blends for sustainable horticultural applications. Green Chemistry, 17(1):380-393. 